\title{
Glucose ingestion during exercise blunts exercise induced gene expression of skeletal muscle fat oxidative genes
}

Citation for published version (APA):

Civitarese, A. E., Hesselink, M. K., Russell, A. P., Ravussin, E., \& Schrauwen, P. (2005). Glucose ingestion during exercise blunts exercise induced gene expression of skeletal muscle fat oxidative genes. American Journal of Physiology : Endocrinology and Metabolism, 289(6), E1023-E1029. https://doi.org/10.1152/ajpendo.00193.2005

Document status and date:

Published: 01/01/2005

DOI:

10.1152/ajpendo.00193.2005

Document Version:

Publisher's PDF, also known as Version of record

Document license:

Taverne

Please check the document version of this publication:

- A submitted manuscript is the version of the article upon submission and before peer-review. There can be important differences between the submitted version and the official published version of record.

People interested in the research are advised to contact the author for the final version of the publication, or visit the DOI to the publisher's website.

- The final author version and the galley proof are versions of the publication after peer review.

- The final published version features the final layout of the paper including the volume, issue and page numbers.

Link to publication

\footnotetext{
General rights rights.

- You may freely distribute the URL identifying the publication in the public portal. please follow below link for the End User Agreement:

www.umlib.nl/taverne-license

Take down policy

If you believe that this document breaches copyright please contact us at:

repository@maastrichtuniversity.nl

providing details and we will investigate your claim.
}

Copyright and moral rights for the publications made accessible in the public portal are retained by the authors and/or other copyright owners and it is a condition of accessing publications that users recognise and abide by the legal requirements associated with these

- Users may download and print one copy of any publication from the public portal for the purpose of private study or research.

- You may not further distribute the material or use it for any profit-making activity or commercial gain

If the publication is distributed under the terms of Article $25 \mathrm{fa}$ of the Dutch Copyright Act, indicated by the "Taverne" license above, 


\title{
Glucose ingestion during exercise blunts exercise-induced gene expression of skeletal muscle fat oxidative genes
}

\author{
Anthony E. Civitarese, ${ }^{1}$ Matthijs K. C. Hesselink, ${ }^{2}$ Aaron P. Russell, ${ }^{3}$ \\ Eric Ravussin, ${ }^{1}$ and Patrick Schrauwen ${ }^{4}$ \\ ${ }^{1}$ Pennington Biomedical Research Center, Baton Rouge, Louisiana; Departments of ${ }^{2}$ Movement Sciences \\ and ${ }^{4}$ Human Biology, Nutrition and Toxicology Research Institute, Maastricht University, \\ Maastricht, The Netherlands; and ${ }^{3}$ Romande Rehabilitation Clinic, SUVACare, Sion, Switzerland
}

Submitted 3 May 2005; accepted in final form 14 July 2005

\begin{abstract}
Civitarese, Anthony E., Matthijs K. C. Hesselink, Aaron P. Russell, Eric Ravussin, and Patrick Schrauwen. Glucose ingestion during exercise blunts exercise-induced gene expression of skeletal muscle fat oxidative genes. Am J Physiol Endocrinol Metab 289: E1023-E1029, 2005. First published July 19, 2005; doi:10.1152/ajpendo.00193.2005.- Ingestion of carbohydrate during exercise may blunt the stimulation of fat oxidative pathways by raising plasma insulin and glucose concentrations and lowering plasma free fatty acid (FFA) levels, thereby causing a marked shift in substrate oxidation. We investigated the effects of a single 2-h bout of moderate-intensity exercise on the expression of key genes involved in fat and carbohydrate metabolism with or without glucose ingestion in seven healthy untrained men $(22.7 \pm 0.6 \mathrm{yr}$; body mass index: $23.8 \pm 1.0 \mathrm{~kg} / \mathrm{m}^{2}$; maximal $\mathrm{O}_{2}$ consumption: $3.85 \pm 0.21 \mathrm{l} / \mathrm{min}$ ). Plasma FFA concentration increased during exercise $(P<0.01)$ in the fasted state but remained unchanged after glucose ingestion, whereas fat oxidation (indirect calorimetry) was higher in the fasted state vs. glucose feeding $(P<0.05)$. Except for a significant decrease in the expression of pyruvate dehydrogenase kinase- $4(P<0.05)$, glucose ingestion during exercise produced minimal effects on the expression of genes involved in carbohydrate utilization. However, glucose ingestion resulted in a decrease in the expression of genes involved in fatty acid transport and oxidation (CD36, carnitine palmitoyltransferase-1, uncoupling protein 3 , and $5^{\prime}$-AMP-activated protein kinase$\left.\alpha_{2} ; P<0.05\right)$. In conclusion, glucose ingestion during exercise decreases the expression of genes involved in lipid metabolism rather than increasing genes involved in carbohydrate metabolism.
\end{abstract}

skeletal muscle gene expression; exercise-diet interaction

SKELETAL MUSCLE HAS THE REMARKABLE CAPACITY to respond and adapt to the physical and metabolic loads imposed by exercise. At the molecular level, these adaptations include the increased capacity for oxidative metabolism of both carbohydrate (CHO) and fatty acids (FA). An enhanced capacity for $\mathrm{CHO}$ oxidation after exercise training is associated with enhanced insulin receptor substrate-1 (IRS-1; see Refs. 17 and 30) and phosphatidylinositol 3-kinase (PI 3-kinase) signaling (16) and increased glucose transporter protein 4 (GLUT4; see Ref. 14). Likewise, improvements in fat metabolism after endurance training are facilitated by the upregulation of the FA transport protein (FAT/CD36), the mitochondrial transporter carnitine palmitoyltransferase I (CPT I; see Ref. 22), the uncoupling protein-3 (UCP3; see Ref. 37), and $\beta$-hydroxyacyl-CoA dehydrogenase ( $\beta$-HAD; see Ref. 39). These adaptations enable the increased provision and oxidation of nutrients during sustained

Address for reprint requests and other correspondence: E. Ravussin, Dept. of Human Physiology, Pennington Biomedical Research Center, 6400 Perkins Rd., Baton Rouge, LA 70808 (e-mail: RavussE@pbrc.edu). exercise activity, in addition to enabling rapid restoration of preexercise $\mathrm{CHO}$ and lipid energy stores.

There are many possible sites of cellular control that contribute to improved substrate uptake, transport, and oxidation under periods of increased muscular contraction. Recent interest has focused on the impact of muscular activity on the transcription and expression of genes encoding key proteins involved in $\mathrm{CHO}$ metabolism and mitochondrial pathways. Typically, there is a transient increase in the cellular abundance of many genes after exercise, with expression peaking within $4 \mathrm{~h}(31,43)$ and returning toward or to baseline levels within $24 \mathrm{~h}$ (48). This transient increase in mRNA species is coupled to the metabolic and functional adaptations that occur after repeated exercise sessions. Thus the intensity, type, and duration of the exercise session differentially influence both the species of gene transcripts and the extent to which gene expression is increased.

The specificity of the genes responding to an exercise session indicates that additional influences such as diet may interact to regulate postexercise gene expression. Several studies have addressed the impact of diet on human skeletal muscle gene expression. For example, glucose ingestion during exercise may create an unusual situation in which genes involved in fat metabolism may be stimulated by exercise but inhibited by the preferential usage of CHO. Our laboratory (5) and others (15) have shown that a preexercise glucose load reduces fat availability to the muscle (secondary to insulin-mediated decrease in adipose tissue lipolysis), thus reducing the entry of long-chain FA in the mitochondria. Consistent with these data, after an intense exercise session to lower muscle glycogen concentrations, as little as $48 \mathrm{~h}$ of a high-CHO or a high-fat diet to either restore or maintain suppressed muscle glycogen resulted in coordinated alterations in genes encoding key proteins for either CHO or lipid metabolism (15). Only one study has addressed whether the proceeding diet influences gene expression in the recovery period after exercise. In this study, intense exercise and a 24-h dietary manipulation resulted in either low or high muscle glycogen levels. Low muscle glycogen levels were found to increase the transcriptional activation of a range of metabolic genes in the recovery period after exercise (15).

Despite the capacity of diet and muscle substrate stores to influence gene expression, no published study has described the actions of glucose ingestion immediately proceeding, during, and after exercise on the skeletal muscle mRNA levels of

The costs of publication of this article were defrayed in part by the payment of page charges. The article must therefore be hereby marked "advertisement" in accordance with 18 U.S.C. Section 1734 solely to indicate this fact. 
genes involved in $\mathrm{CHO}$ metabolism. This is despite the widespread recommendations for athletes to ingest CHO-rich beverages during and immediately after exercise cessation to treat dehydration and restore glycogen levels. Accordingly, the present study examined the transient regulation of key metabolic genes during endurance exercise with or without glucose ingestion within the first few hours postexercise.

\section{METHODS}

Subjects. As previously described, seven healthy $[22.7 \pm 0.6 \mathrm{yr}$; body mass index: $23.8 \pm 1.0 \mathrm{~kg} / \mathrm{m}^{2}$; maximal $\mathrm{O}_{2}$ consumption $\left.\left(\dot{\mathrm{V}}_{2} \max \right): 3.85 \pm 0.21 \mathrm{l} / \mathrm{min}\right]$ untrained male volunteers participated in this study (36). None of the subjects participated in endurance sports, but all were moderately active. All subjects gave their written informed consent, and the study was approved by the Medical-Ethical Committee of Maastricht University.

Experimental design. All participants were studied on two occasions in a blinded, randomized crossover design with either the water or the glucose trial. These two trials were separated by $1 \mathrm{wk}$. The protocol for trial 1 was as follows. Prior to the experiment, $\mathrm{V}_{2}$ max was determined by an incremental exercise test on an electromagnetically braked cycle ergometer (Lode Excalibur, Groningen, The Netherlands). On test days, after an overnight fast, subjects had a percutaneous muscle biopsy taken from the vastus lateralis muscle, and muscle tissue was immediately frozen in liquid nitrogen. A Teflon cannula was inserted in an antecubital vein for blood sampling (time $-60 \mathrm{~min}$ ). After ingestion of $1.4 \mathrm{~g} / \mathrm{kg}$ body wt glucose solution (dissolved in water to a $20 \%$ solution and flavored with $1 \mathrm{ml}$ of lemon juice) and after $1 \mathrm{~h}$ of bed rest, subjects started exercising at $50 \%$ of maximal power output (at time $0 \mathrm{~min}$ ) for $2 \mathrm{~h}$. Blood samples were taken at time 30,60,90,120,180, 240,300, and $360 \mathrm{~min}$. Subjects ingested an additional $0.35 \mathrm{~g} / \mathrm{kg}$ body wt glucose solution (dissolved in water to a $10 \%$ solution and flavored with $1 \mathrm{ml}$ of lemon juice) at time $-10,30,60,90,180,240$, and $300 \mathrm{~min}$. Immediately after cessation of exercise, a second muscle biopsy was taken (time $=120$ $\mathrm{min}$ ), followed by two more at $1 \mathrm{~h}($ time $=180 \mathrm{~min}$ ) and $4 \mathrm{~h}$ (time $=$ $360 \mathrm{~min}$ ) postexercise. To avoid the confounding and independent effects of repeated muscle sampling (42), muscle biopsy samples were taken in a randomized order at four different sites and to the opposite leg to trial 1. Indirect calorimetry was performed continuously at rest and in the last $10 \mathrm{~min}$ of every half-hour during exercise. From the recorded $\dot{\mathrm{V}}_{2}$ and $\dot{\mathrm{V}}_{\mathrm{CO}_{2}}$ (Oxycon- $\beta$, Mijnhardt, The Netherlands), $\mathrm{CHO}$ and fat oxidation rates and energy expenditure were calculated using the formulas of Peronnet and Massicott (28). The protocol for trial 2 was as follows. This was performed exactly the same as trial 1 ; however, subjects remained fasted before, during, and after exercise and received lemon-flavored water without glucose.

Blood analysis. Blood was collected in EDTA tubes and immediately centrifuged at $4,000 \mathrm{rpm}$ for $10 \mathrm{~min}$ at $4^{\circ} \mathrm{C}$. Plasma was frozen in liquid nitrogen and stored at $-80^{\circ} \mathrm{C}$. Plasma glucose was determined using the hexokinase method (Roche, Basel, Switzerland) and plasma free fatty acid (FFA) using the Wako NEFA C test kit (Wako Chemicals, Neuss, Germany).

Real-time quantitative RT-PCR. Total RNA was extracted using the acid-phenol method of Chomczynski and Sacchi (4), with an additional DNase digestion step with concomitant acid-phenol extraction and ethanol precipitation. Primer and probe sequences were designed using Primer Express software package version 1.0 (PerkinElmer, Norwalk, CT) and are given in Table 1. Gene expression was measured using quantitative RT-PCR on an ABI Prism 7700 sequence detector. Briefly, $20 \mathrm{ng}$ diluted RNA was added to $2 \times$ TaqMan One-Step RT-PCR Master Mix (Applied Biosystems). PCR conditions consisted of a two-step PCR. Step 1 included a 30-min reverse transcription stage at $48^{\circ} \mathrm{C}$ and another at $95^{\circ} \mathrm{C}$ for $10 \mathrm{~min}$ to activate AmpliTaq Gold DNA Polymerase. Step 2 consisted of 40 cycles of a denaturing step at $95^{\circ} \mathrm{C}$ for $15 \mathrm{~s}$ and an extension stage at $60^{\circ} \mathrm{C}$ for 1 min. All samples for each gene were run in duplicate simultaneously to control for amplification efficiency. To compensate for RNA input variation and the efficiency of reverse transcription, cyclophilin B mRNA was quantitated, and results were normalized to these values. To ascertain whether cyclophilin B gene expression was modified by acute exercise and glucose ingestion, absolute gene expression levels were quantitated and analyzed as previously described (43). No exercise-dietary effect was detected on the absolute expression of cyclophilin B, implying similar initial mRNA concentrations between samples.

Statistical analysis. Repeated-measures ANOVA was performed to examine differences in measured parameters between the glucose and fasted treatments at any time point. Two-way ANOVA was performed to examine the interaction between diet and exercise. Because all the variables were normally distributed, Pearson correlation coefficients were calculated to determine the relationship between selected variables within each treatment trial. All data are presented as means \pm SE. A $P$ value $<0.05$ was considered statistically significant.

\section{RESULTS}

Energy and substrate metabolism. As expected, blood glucose concentration decreased during the fasted state, relative to

Table 1. Gene primer and probe sequences

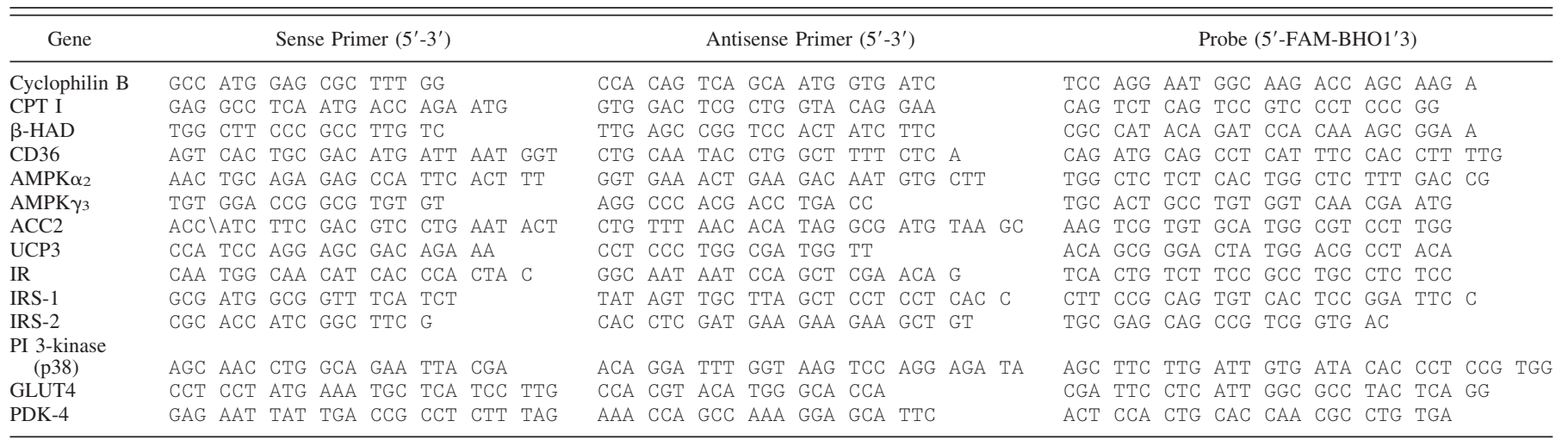

CPT I, carnitine palmitoltransferase-1 (muscle isoform); $\beta$-HAD, $\beta$-hydroxyacyl-CoA dehydrogenase; CD36, fatty acid transport protein; AMPK $\alpha_{2}$, 5-AMP-activated protein kinase $\alpha_{2}$-subunit; AMPK $\gamma_{3}, 5^{\prime}$-AMP-activated protein kinase $\gamma_{3}$-subunit; ACC2, acetyl-CoA carboxylase 2; UCP3, uncoupling protein-3; IR, insulin receptor; IRS-1, insulin receptor substrate-1; IRS-2, insulin receptor substrate-2; PI 3-kinase (p38), p38 subunit of phosphatidylinositol 3-kinase; GLUT4, glucose transporter 4; PDK-4, pyruvate dehydrogenase kinase-4. 
A

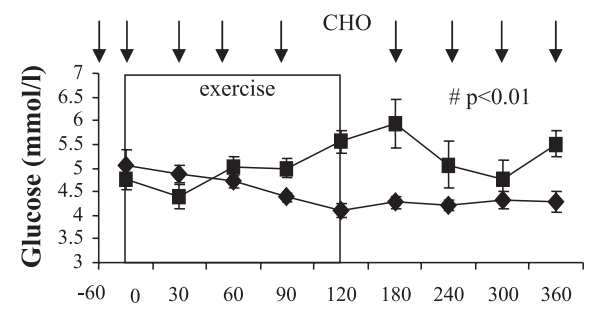

C

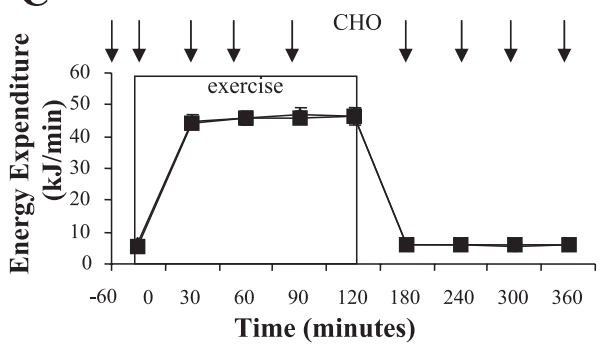

B

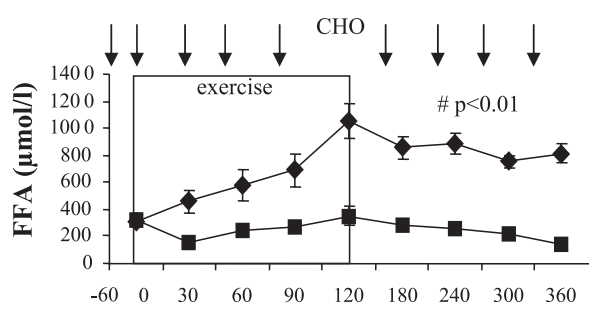

D

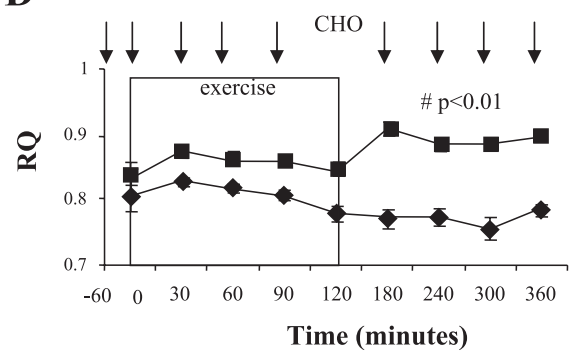

Fig. 1. Blood glucose $(A)$, plasma levels of free fatty acid (FFA; $B)$, energy expenditure $(C)$, and respiratory quotient $(\mathrm{RQ} ; D)$ during and after $2 \mathrm{~h}$ of cycling at $50 \%$ maximal power output $\left(\mathrm{W}_{\max }\right)$, with (匹) and without ( $\bullet$ fasted state) glucose ingestion. $\# P<0.05$ compared with fasting trial. $\mathrm{CHO}$, carbohydrate feeding. Data are means \pm SE. the fed state $(P<0.01$; Fig. $1 A)$, and plasma FFA concentration increased during exercise in the fasted state and remained unchanged after glucose ingestion $(P<0.01$; Fig. $1 B)$. There was no treatment effect on energy expenditure (Fig. 1C), whereas respiratory quotient (RQ) was lower in the fasted state vs. glucose feeding $(P<0.01$; Fig. $1 D)$. Accordingly, fat oxidation was $37 \pm 9 \%$ higher in the fasted state relative to the glucose trial (data not shown; see Ref. 36).

$m R N A$ quantification. The effect of short-term moderateintensity exercise with or without glucose consumption on the
mRNA level of genes involved in CHO metabolism is shown in Fig. 2, whereas the effect on genes involved in fat metabolism is shown in Fig. 3.

$\mathrm{CHO}$ metabolism gene expression. Exercise with glucose ingestion did not alter the mRNA expression of the insulin receptor (IR; data not shown), insulin receptor substrate-2, (IRS-2; data not shown), IRS-1, and PI 3-kinase over time compared with exercise in the fasted state (Fig. 2). However, exercise did increase PI 3-kinase mRNA expression $4 \mathrm{~h}$ after exercise in either treatment group (Fig. 2B). With regard to
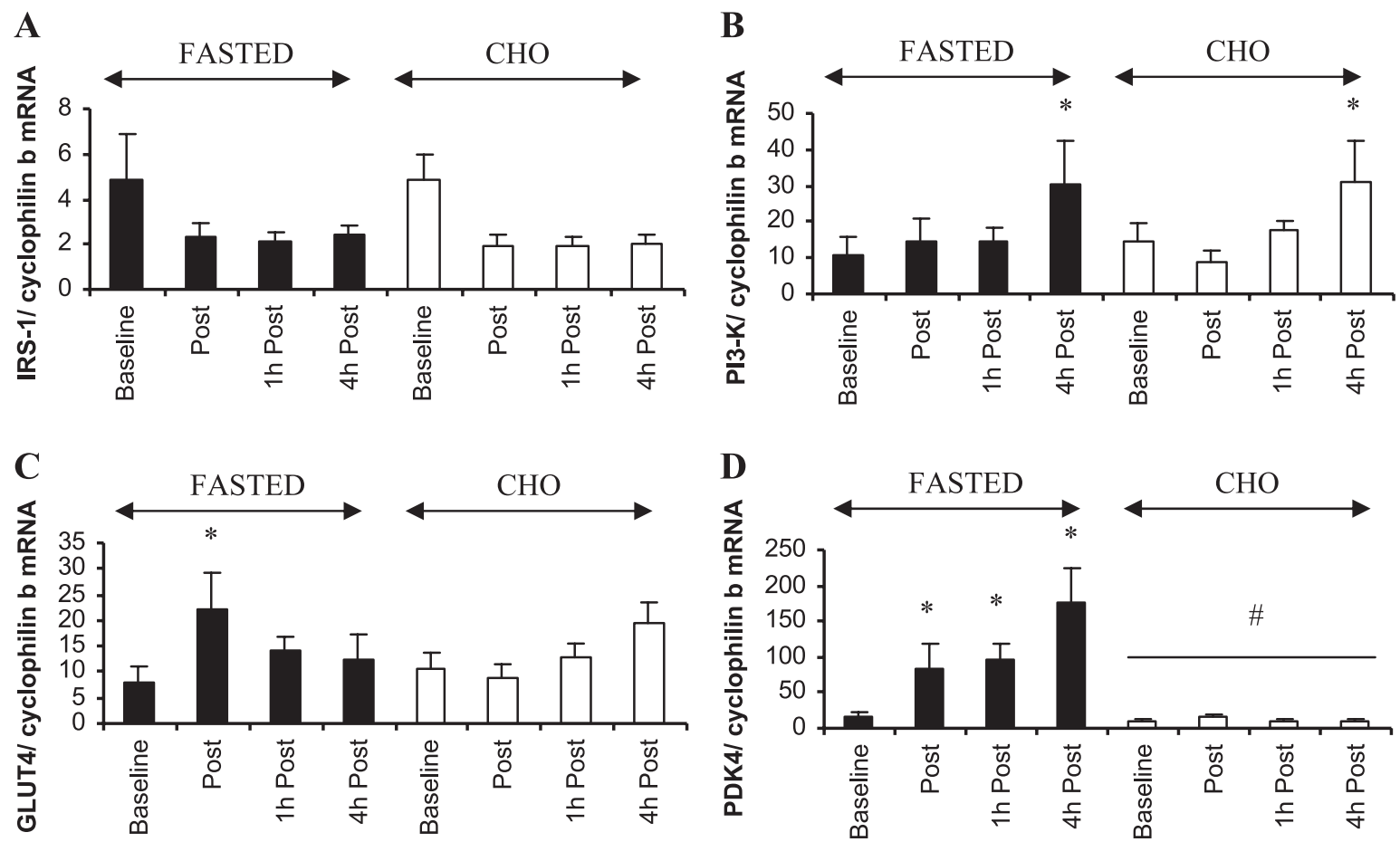

Fig. 2. Skeletal muscle mRNA expression of the insulin receptor substrate-1 (IRS-1; $A$ ), phosphatidylinositol 3-kinase (PI3K; $B$ ), glucose transporter 4 (GLUT4; $C$ ), and pyruvate dehydrogenase kinase- 4 (PDK-4;D) during and after $2 \mathrm{~h}$ of cycling at $50 \% \mathrm{~W}_{\max }$, with (open bars) and without (filled bars; fasted state) glucose ingestion. A repeated-measures ANOVA was performed to discriminate between differences due to the effects of glucose treatment and/or time. Values are means \pm SE. $* P<0.05$ compared with baseline. Significant treatment effect, ${ }^{*} P<0.05$ and $\# P<0.01$. 

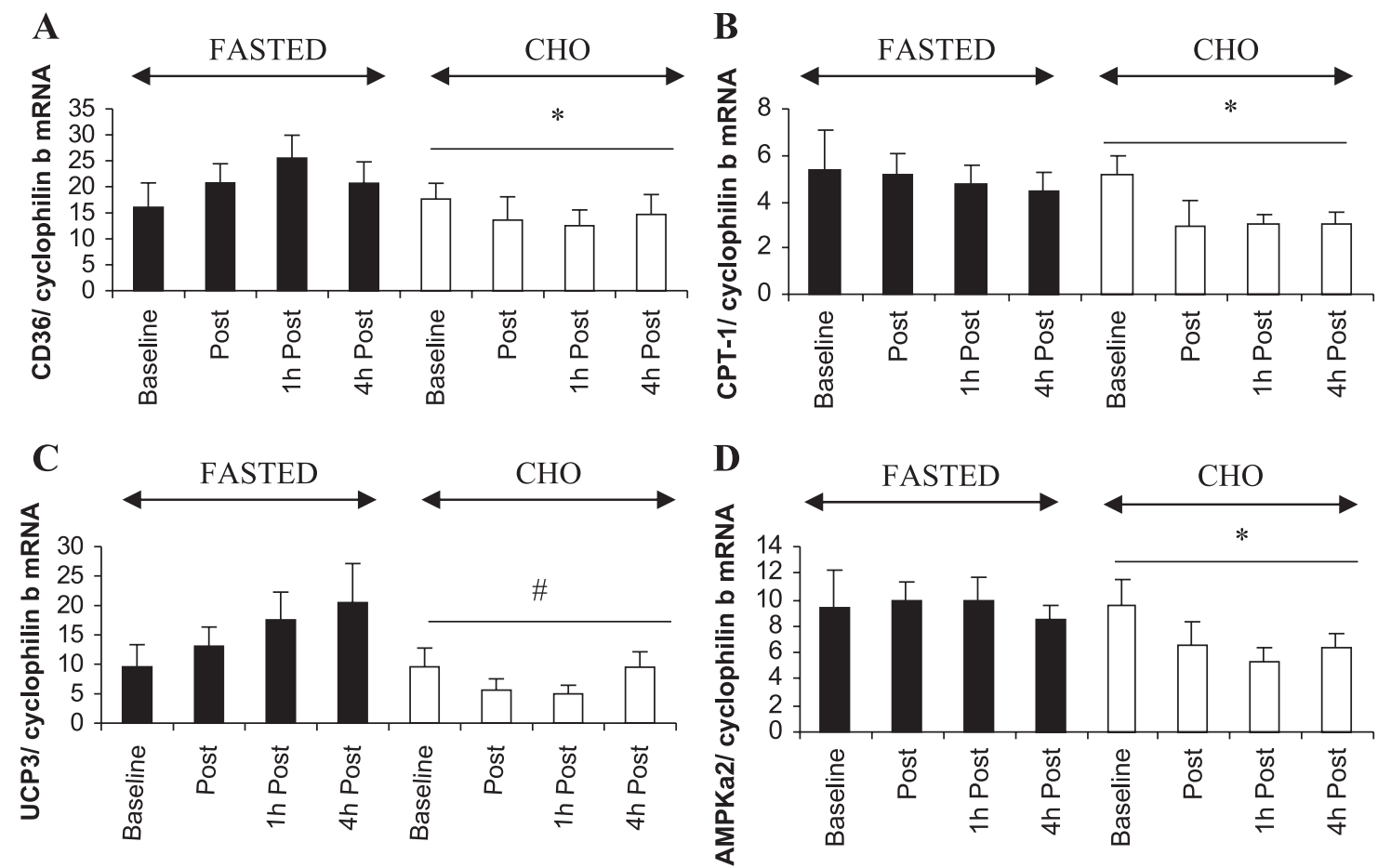

Fig. 3. Skeletal muscle gene expression of CD36 (A), carnitine palmitoyltransferase I (CPT I; $B$ ), uncoupling protein-3 (UCP3; $C$ ) and AMP-activated protein kinase $\alpha_{2}$-subunit (AMPK $\alpha_{2} ; D$ ) during and after $2 \mathrm{~h}$ of cycling at $50 \% \mathrm{~W}_{\max }$, with (open bars) and without (filled bars; fasted state) glucose ingestion. Values are means $\pm \mathrm{SE}$. A repeated-measures ANOVA was performed to discriminate between differences due to the effects of glucose treatment and/ or time. Significant treatment effects, $* P<0.05$ and $\# P<0.01$.

GLUT4, glucose feeding did blunt the significant increase in the expression level of GLUT4 that was observed after exercise in the fasted state $(P<0.05)$, indicating a treatment effect. Furthermore, glucose ingestion was associated with a time-bytreatment suppression of pyruvate dehydrogenase-4 (PDK-4) mRNA compared with fasting exercise $(P<0.01)$.

Fat metabolism gene expression. Exercise with glucose ingestion caused a time-by-treatment suppression of CD36 $(P<0.05)$, CPT I $(P<0.05)$, UCP3 $(P<0.01)$, and 5 -AMP-activated protein kinase (AMPK) $\alpha_{2}$ mRNA $(P<$ 0.05 ) levels compared with the fasted state (Fig. 3). No exercise-diet interaction was observed for acetyl-CoA carboxylase 2 (ACC2), $\beta$-HAD, and AMPK $\gamma_{3}$ (data not shown).

\section{DISCUSSION}

During exercise and the subsequent recovery period, the type and quantity of fuel used depends on the interplay between the fuels available from the diet and storage depots, the intensity and duration of the activity, and the training status of the subject. Accordingly, it has long been known that a preexercise glucose load reduces fat oxidation during low- to moderate-intensity exercise (up to $\sim 60 \% \dot{\mathrm{V}}_{2}$ max ; see Ref. 40 ). $\mathrm{CHO}$ feeding markedly influences circulating metabolites (increasing glucose concentrations and reducing FFA availability) and presumably changes the pattern of gene transcription. Several studies have shown that sustained training-induced cellular adaptation is the result of the cumulative effects of repeated exercise bouts. However, the initial signaling responses that lead to long-term adaptations can occur in response to each bout of exercise $(12,31)$. In this context, we examined the regulation of genes involved in $\mathrm{CHO}$ and fat metabolism in response to a single 2-h bout of moderateintensity exercise and in the presence or absence of repeated glucose ingestion. Our first major finding was that glucose consumption lowered the mRNA expression of genes involved in FA transport and oxidation (CD36, UCP3, CPT I, and AMPK $\alpha_{2}$ ) and of PDK-4, a gene involved in the regulation of glycolysis. This treatment lowering of gene expression over "time" was associated with reduced FFA concentrations and an increase in $\mathrm{CHO}$ oxidation (higher RQ), albeit, at an exercise intensity normally favoring oxidation of lipids (40). These data suggest several important findings. Firstly, acute changes in whole body substrate flux favoring $\mathrm{CHO}$ metabolism can modify the expression level of genes involved in transport and oxidation of lipids immediately after exercise. Second, no time-by-treatment effect was observed in our set of CHO metabolism genes (IR, IRS-1/2, PI 3-kinase, and GLUT4), implying that an increased glucose flux during exercise does not upregulate genes involved in insulin signaling and is an effect inherent to the contracting muscle.

The mechanism by which consumption of $\mathrm{CHO}$ leads to a decrease in gene expression of fat metabolism during exercise is unclear; however, insulin may play a role. We have previously shown, in a similar experiment, that insulin levels remain elevated during exercise with glucose ingestion compared with exercise in the fasted state (5). Therefore, the elevated circulating insulin produced by the glucose load could have a negative feedback on gene expression. In support of this concept, Rome et al. (33) recently demonstrated that insulin acts on global gene expression by regulating the mRNA levels of genes involved in transcription, energy metabolism, and intracellular signaling. More specifically, insulin has also been 
shown to suppress PDK-4 mRNA (21), which is consistent with the current findings.

Conversely, the reduced expression of lipid metabolism genes may have been due in part to suppressed lipolysis and a lowering of circulating FFA. In support of this mechanism, we have recently demonstrated that the administration of acipimox reduced both fat oxidation and UCP3 mRNA levels (13) by blocking lipolysis and reducing FFA plasma concentration. It is well established that FFAs, via their interaction with the peroxisome proliferator activator receptor (PPAR) family of nuclear hormone receptors, can regulate systemic FA metabolism via ligand-dependent transcriptional activation of target genes (20). For example, fasting increases both the lipid supply to oxidative tissue and the expression of both PDK-4 and UCP3 in the skeletal muscle of rats $(11,41)$ via an FFAmediated activation of PPAR $\alpha$ (46). Interestingly, in humans, the expression of muscle CPT I, the rate-limiting step in fat oxidation (23), and CD36, an important transporter of longchain FA, is also regulated by PPAR $\alpha$ (35). Importantly, in our study, increasing blood glucose concentrations during $\mathrm{CHO}$ ingestion was accompanied with a lowering of CD36, CPT I, and UCP3 mRNA over time and reduced lipid flux and oxidation, suggesting that a reduction in ligands for PPAR can reduce the expression of downstream targets.

The main function of PDK-4 is the suppression of glycolysis by phosphorylating and inactivating the pyruvate dehydrogenase complex (11). The activity of PDK-4 is regulated by glucose flux in the cell but may also be enhanced with increased lipid supply and utilization $(11,25)$. Consistent with these facts, in the present study, we observed an induction in PDK-4 transcription during the entire fasting trial that was associated with high rates of fat oxidation. Conversely, glucose feeding caused a highly significant time-by-treatment suppression of PDK-4 mRNA that was associated with increased CHO oxidation, as evidenced by an elevated RQ. These data are in agreement with previous studies that demonstrate that substrate availability has a profound effect on PDK-4 gene expression $(29,32)$. Recently, Arkinstall et al. (1) demonstrated that PDK-4 transcription is suppressed by 2 days of $\mathrm{CHO}$ feeding to replenish glycogen stores. Conversely, other studies have shown that glucose consumption is not sufficient to inhibit increased PDK-4 transcription during exercise $(1,30)$. This discrepancy is most likely the result of the timing of the meal ingestion. Several studies have demonstrated that a single preexercise glucose load causing hyperinsulinemia results in a rapid and sustained drop in blood glucose concentrations during submaximal exercise $(6,7)$. However, in this study, we provided a constant flux of ingested glucose that resulted in elevated plasma glucose concentration and oxidation during the entire glucose trial (Fig. 1A). Glycogen is also a known signaling molecule that can regulate gene transcription, although it is unlikely that it would have contributed to changes in PDK-4 mRNA expression in this current experimental paradigm. It was previously shown that the type of exercise trial used in this study does not alter glycogen oxidation (18). These data suggest that changes in PDK-4 transcription (or the subset of lipid metabolism genes examined in this study) can be repressed during exercise conditions favoring fat oxidation as a result of increased glucose flux and oxidation and are independent of muscle glycogen concentration.
Many of the adaptations taking place during exercise are proposed to involve AMPK, a member of a metabolite-sensing protein kinase family that functions as a metabolic "fuel gauge" in skeletal muscle (9). However, the independent effect of glucose supplementation on AMPK mRNA expression during exercise is unknown. During exercise, AMPK becomes activated in skeletal muscle in response to changes in cellular energy status (e.g., increased AMP-to-ATP and creatine-tophosphocreatine ratios; see Ref. 44). In turn, AMPK can phosphorylate ACC2, which leads to the inhibition of ACC2 activity and a consequent reduction in the malonyl-CoA content, thereby derepressing CPT I activity and increasing skeletal muscle FA oxidation (44). Although we and others $(24,26)$ did not observe an upregulation of $\mathrm{AMPK} \alpha_{2}$ mRNA with exercise in the fasted state, the reduced $\mathrm{AMPK} \alpha_{2}$ mRNA expression observed in this study with glucose feeding and the suppression of fat metabolism genes in this condition is consistent with the fact that AMPK activate pathways involved in FA metabolism when cellular substrate levels decline (2). However, we acknowledge, the extent to which a protein and posttranslational modifications might be modified in response to an exercise-diet interaction cannot be predicted from an increase in mRNA level; however, it has previously been reported that the concentration of mRNA for genes encoding for substrate metabolism is accompanied by a concomitant increase in the cellular content of the transcribed protein $(3,29)$ and, presumably, function. In addition, without the inclusion of control subjects with rest \pm fasting or glucose, it is not possible to attribute the alterations observed after glucose feeding to a modulation of $\mathrm{CHO}$ treatment only. Future studies should be aimed at examining this discrepancy.

Results from this study and others $(12,31)$ demonstrate an increase in GLUT4 mRNA and protein (8) expression after a single bout of moderate-intensity exercise. However, the increase in GLUT4 gene expression in the postexercise period was reduced during the glucose trial. To the best of our knowledge, this is the first study to demonstrate the acute reduction in GLUT4 gene expression in response to dietary manipulation. Recent data suggest that insulin is an important regulator of GLUT4 mRNA after exercise in rats (19). However, muscle contraction during exercise has an insulin-independent effect on muscle glucose uptake (34). The two main mediators of this process are thought to involve muscle glycogen content and AMPK activity, as well as several downstream kinases from AMPK, including the p38 mitogen-activated protein kinase (47) and the $\mathrm{Ca}^{2+}$-sensitive class of atypical protein kinase C (27). It has repeatedly been shown, both in vivo and in vitro, that glucose uptake increases when muscle glycogen is low $(10,45)$. In this context, the coordinated decrease in AMPK $\alpha_{2}$ and GLUT4 mRNA abundance might be expected to decrease protein expression and thereby provide a negative feedback that limits further storage of muscle glycogen when glycogen concentrations and the glucose flux in the myocyte are high. This hypothesis fits well with data from the present study that demonstrate that glucose oxidation was elevated and PDK-4 and GLUT4 gene expression lowered during the postexercise period in the glucose trial.

In summary, we provide evidence that glucose ingestion during moderate-intensity exercise inhibits the expression of genes involved in the transport and oxidation of lipids (CD36, CPT I, UCP3, and $\mathrm{AMPK} \alpha_{2}$ ) and downregulates PDK-4, 
which is involved in glycolysis suppression. The change in mRNA expression was rapid (1-4 h) and occurred at an exercise intensity relying mostly on fat metabolism. Therefore, acute exercise with glucose ingestion does not result in adaptive changes in muscle that favor the capacity for carbohydrate oxidation/metabolism but rather suppresses the exercise-induced adaptive changes that would favor fat oxidative capacity.

\section{ACKNOWLEDGMENTS}

We thank Dr. David Cameron-Smith and Stacy Carling for critical comments on manuscript preparation.

\section{REFERENCES}

1. Arkinstall MJ, Tunstall RJ, Cameron-Smith D, and Hawley JA. Regulation of metabolic genes in human skeletal muscle by short-term exercise and diet manipulation. Am J Physiol Endocrinol Metab 287: E25-E31, 2004.

2. Aschenbach WG, Sakamoto K, and Goodyear LJ. 5' Adenosine monophosphate-activated protein kinase, metabolism and exercise. Sports Med 34: 91-103, 2004

3. Cameron-Smith D, Burke LM, Angus DJ, Tunstall RJ, Cox GR, Bonen A, Hawley JA, and Hargreaves M. A short-term, high-fat diet up-regulates lipid metabolism and gene expression in human skeletal muscle. Am J Clin Nutr 77: 313-318, 2003.

4. Chomczynski P and Sacchi N. Single-step method of RNA isolation by acid guanidinium thiocyanate-phenol-chloroform extraction. Anal Biochem 162: 156-159, 1987.

5. Coyle EF, Jeukendrup AE, Wagenmakers AJ, and Saris WH. Fatty acid oxidation is directly regulated by carbohydrate metabolism during exercise. Am J Physiol Endocrinol Metab 273: E268-E275, 1997.

6. Febbraio MA, Keenan J, Angus DJ, Campbell SE, and Garnham AP. Preexercise carbohydrate ingestion, glucose kinetics, and muscle glycogen use: effect of the glycemic index. J Appl Physiol 89: 1845-1851, 2000.

7. Febbraio MA and Stewart KL. CHO feeding before prolonged exercise: effect of glycemic index on muscle glycogenolysis and exercise performance. J Appl Physiol 81: 1115-1120, 1996.

8. Greiwe JS, Hickner RC, Hansen PA, Racette SB, Chen MM, and Holloszy JO. Effects of endurance exercise training on muscle glycogen accumulation in humans. $J$ Appl Physiol 87: 222-226, 1999.

9. Hardie DG. AMP-activated protein kinase: a key system mediating metabolic responses to exercise. Med Sci Sports Exerc 36: 28-34, 2004.

10. Hespel $\mathbf{P}$ and Richter EA. Glucose uptake and transport in contracting, perfused rat muscle with different pre-contraction glycogen concentrations. J Physiol 427: 347-359, 1990.

11. Hildebrandt AL and Neufer PD. Exercise attenuates the fasting-induced transcriptional activation of metabolic genes in skeletal muscle. Am J Physiol Endocrinol Metab 278: E1078-E1086, 2000.

12. Hildebrandt AL, Pilegaard H, and Neufer PD. Differential transcriptional activation of select metabolic genes in response to variations in exercise intensity and duration. Am J Physiol Endocrinol Metab 285: E1021-E1027, 2003.

13. Hoeks J, van Baak MA, Hesselink MK, Hul GB, Vidal H, Saris WH, and Schrauwen P. Effect of $\beta_{1}$ - and $\beta_{2}$-adrenergic stimulation on energy expenditure, substrate oxidation, and UCP3 expression in humans. Am J Physiol Endocrinol Metab 285: E775-E782, 2003.

14. Holten MK, Zacho M, Gaster M, Juel C, Wojtaszewski JF, and Dela F. Strength training increases insulin-mediated glucose uptake, GLUT4 content, and insulin signaling in skeletal muscle in patients with type 2 diabetes. Diabetes 53: 294-305, 2004.

15. Horowitz JF, Mora-Rodriguez R, Byerley LO, and Coyle EF. Lipolytic suppression following carbohydrate ingestion limits fat oxidation during exercise. Am J Physiol Endocrinol Metab 273: E768-E775, 1997.

16. Houmard JA, Shaw CD, Hickey MS, and Tanner CJ. Effect of short-term exercise training on insulin-stimulated PI 3-kinase activity in human skeletal muscle. Am J Physiol Endocrinol Metab 277: E1055E1060, 1999 .

17. Howlett KF, Sakamoto K, Hirshman MF, Aschenbach WG, Dow M, White MF, and Goodyear LJ. Insulin signaling after exercise in insulin receptor substrate-2-deficient mice. Diabetes 51: 479-483, 2002.

18. Jeukendrup AE, Raben A, Gijsen A, Stegen JH, Brouns F, Saris WH, and Wagenmakers AJ. Glucose kinetics during prolonged exercise in highly trained human subjects: effect of glucose ingestion. $J$ Physiol 515: 579-589, 1999.

19. Kuo CH, Hwang H, Lee MC, Castle AL, and Ivy JL. Role of insulin on exercise-induced GLUT-4 protein expression and glycogen supercompensation in rat skeletal muscle. $J$ Appl Physiol 96: 621-627, 2004.

20. Latruffe $\mathbf{N}$ and Vamecq J. Evolutionary aspects of peroxisomes as cell organelles, and of genes encoding peroxisomal proteins. Biol Cell 92: 389-395, 2000.

21. Lee FN, Zhang L, Zheng D, Choi WS, and Youn JH. Insulin suppresses PDK-4 expression in skeletal muscle independently of plasma FFA. Am J Physiol Endocrinol Metab 287: E69-E74, 2004.

22. Luiken JJ, Koonen DP, Willems J, Zorzano A, Becker C, Fischer Y, Tandon NN, Van Der Vusse GJ, Bonen A, and Glatz JF. Insulin stimulates long-chain fatty acid utilization by rat cardiac myocytes through cellular redistribution of FAT/CD36. Diabetes 51: 3113-3119, 2002.

23. Mascaro C, Acosta E, Ortiz JA, Marrero PF, Hegardt FG, and Haro D. Control of human muscle-type carnitine palmitoyltransferase I gene transcription by peroxisome proliferator-activated receptor. J Biol Chem 273: 8560-8563, 1998.

24. McGee SL, Howlett KF, Starkie RL, Cameron-Smith D, Kemp BE, and Hargreaves M. Exercise increases nuclear AMPK alpha2 in human skeletal muscle. Diabetes 52: 926-928, 2003.

25. Motojima K, Passilly P, Peters JM, Gonzalez FJ, and Latruffe N. Expression of putative fatty acid transporter genes are regulated by peroxisome proliferator-activated receptor alpha and gamma activators in a tissue- and inducer-specific manner. J Biol Chem 273: 16710-16714, 1998.

26. Musi N, Fujii N, Hirshman MF, Ekberg I, Froberg S, Ljungqvist O, Thorell A, and Goodyear LJ. AMP-activated protein kinase (AMPK) is activated in muscle of subjects with type 2 diabetes during exercise. Diabetes 50: 921-927, 2001.

27. Nielsen JN, Frosig C, Sajan MP, Miura A, Standaert ML, Graham DA, Wojtaszewski JF, Farese RV, and Richter EA. Increased atypical PKC activity in endurance-trained human skeletal muscle. Biochem Biophys Res Commun 312: 1147-1153, 2003.

28. Peronnet $\mathbf{F}$ and Massicotte $\mathbf{D}$. Table of nonprotein respiratory quotient: an update. Can J Sport Sci 16: 23-29, 1991.

29. Peters SJ, Harris RA, Wu P, Pehleman TL, Heigenhauser GJ, and Spriet LL. Human skeletal muscle PDH kinase activity and isoform expression during a 3-day high-fat/low-carbohydrate diet. Am J Physiol Endocrinol Metab 281: E1151-E1158, 2001.

30. Pilegaard H, Keller C, Steensberg A, Helge JW, Pedersen BK, Saltin B, and Neufer PD. Influence of pre-exercise muscle glycogen content on exercise-induced transcriptional regulation of metabolic genes. J Physiol 541: 261-271, 2002.

31. Pilegaard H, Ordway GA, Saltin B, and Neufer PD. Transcriptional regulation of gene expression in human skeletal muscle during recovery from exercise. Am J Physiol Endocrinol Metab 279: E806-E814, 2000.

32. Pilegaard H, Saltin B, and Neufer PD. Effect of short-term fasting and refeeding on transcriptional regulation of metabolic genes in human skeletal muscle. Diabetes 52: 657-662, 2003.

33. Rome S, Clement K, Rabasa-Lhoret R, Loizon E, Poitou C, Barsh GS, Riou JP, Laville M, and Vidal H. Microarray profiling of human skeletal muscle reveals that insulin regulates approximately 800 genes during a hyperinsulinemic clamp. J Biol Chem 278: 18063-18068, 2003.

34. Ryder JW, Kawano Y, Galuska D, Fahlman R, Wallberg-Henriksson H, Charron MJ, and Zierath JR. Postexercise glucose uptake and glycogen synthesis in skeletal muscle from GLUT4-deficient mice. FASEB J 13: 2246-2256, 1999.

35. Sato O, Kuriki C, Fukui Y, and Motojima K. Dual promoter structure of mouse and human fatty acid translocase/CD36 genes and unique transcriptional activation by peroxisome proliferator-activated receptor alpha and gamma ligands. J Biol Chem 277: 15703-15711, 2002.

36. Schrauwen P, Hesselink MK, Vaartjes I, Kornips E, Saris WH, Giacobino JP, and Russell A. Effect of acute exercise on uncoupling protein 3 is a fat metabolism-mediated effect. Am J Physiol Endocrinol Metab 282: E11-E17, 2002.

37. Schrauwen P, Troost FJ, Xia J, Ravussin E, and Saris WH. Skeletal muscle UCP2 and UCP3 expression in trained and untrained male subjects. Int J Obes Relat Metab Disord 23: 966-972, 1999.

38. Schrauwen P, van Aggel-Leijssen DP, Hul G, Wagenmakers AJ, Vidal H, Saris WH, and van Baak MA. The effect of a 3-month low-intensity endurance training program on fat oxidation and acetyl-CoA carboxylase-2 expression. Diabetes 51: 2220-2226, 2002. 
39. Spina RJ, Chi MM, Hopkins MG, Nemeth PM, Lowry OH, and Holloszy JO. Mitochondrial enzymes increase in muscle in response to 7-10 days of cycle exercise. J Appl Physiol 80: 2250-2254, 1996.

40. Spriet LL and Watt MJ. Regulatory mechanisms in the interaction between carbohydrate and lipid oxidation during exercise. Acta Physiol Scand 178: 443-452, 2003.

41. Sugden MC, Lall HS, Harris RA, and Holness MJ. Selective modification of the pyruvate dehydrogenase kinase isoform profile in skeletal muscle in hyperthyroidism: implications for the regulatory impact of glucose on fatty acid oxidation. J Endocrinol 167: 339-345, 2000.

42. Vissing K, Andersen JL, and Schjerling P. Are exercise-induced genes induced by exercise? FASEB J 19: 94-96, 2005.

43. Wadley GD, Tunstall RJ, Sanigorski A, Collier GR, Hargreaves M, and Cameron-Smith D. Differential effects of exercise on insulinsignaling gene expression in human skeletal muscle. $J$ Appl Physiol 90 436-440, 2001.
44. Winder WW and Hardie DG. Inactivation of acetyl-CoA carboxylase and activation of AMP-activated protein kinase in muscle during exercise. Am J Physiol Endocrinol Metab 270: E299-E304, 1996.

45. Wojtaszewski JF, Jorgensen SB, Frosig C, MacDonald C, Birk JB, and Richter EA. Insulin signalling: effects of prior exercise. Acta Physiol Scand 178: 321-328, 2003.

46. Wu P, Inskeep K, Bowker-Kinley MM, Popov KM, and Harris RA. Mechanism responsible for inactivation of skeletal muscle pyruvate dehydrogenase complex in starvation and diabetes. Diabetes 48: 1593-1599, 1999

47. Xi X, Han J, and Zhang JZ. Stimulation of glucose transport by AMP-activated protein kinase via activation of p38 mitogen-activated protein kinase. J Biol Chem 276: 41029-41034, 2001.

48. Yang Y, Creer A, Jemiolo B, and Trappe S. Time course of myogenic and metabolic gene expression in response to acute exercise in human skeletal muscle. J Appl Physiol 98: 1745-1752, 2005.

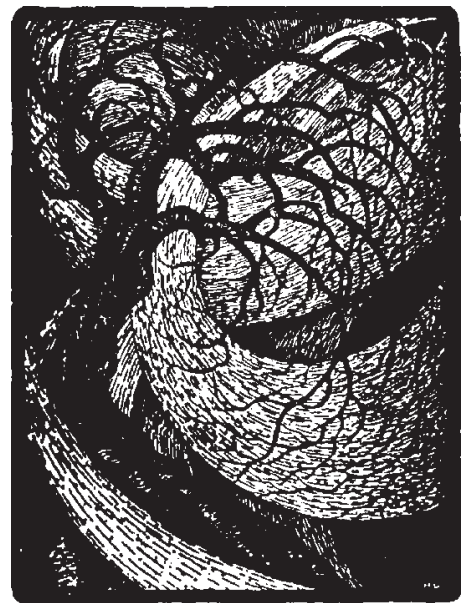

